\title{
The Effectiveness of Internal Control Reporting on Improving Financial Reporting
}

\author{
Shaban Mohammadi ${ }^{1, ~}$, Ali Shirzad ${ }^{2}$ \\ ${ }^{1}$ M.A student in accounting, Hakim Nezami University of Quchan, Iran \\ ${ }^{2} \mathrm{Ph}$.D student in accounting, Ferdowsi University of Mashhad, Iran \\ Email address: Shaban1362@gmail.com
}

Keywords: Reporting, internal controls, improve financial reporting, managers, auditors.

\begin{abstract}
This paper explores the views of managers and independent auditors to audit institutes and organizations associated with the need for a new report entitled Report of the useful internal controls and its impact on the overall improvement of financial reporting, to compare the deals. The method used descriptive survey. According to the study population consisted of directors of listed companies in Tehran Stock Exchange as well as auditors and audit organizations working in the public audit firms and certified public accountants Iran is the Securities and Exchange. The required information was collected using a questionnaire. To analyze the data from the test was used to compare means. The results show that managers and auditors have focused on the usefulness of this type of report. Administrators voluntary reporting on internal control, management, financial reporting improves. The auditors also believe that mandatory reporting of management on internal control, financial reporting does not improve. Other results show that between administrators and auditors in connection with the internal control reporting, there is a significant difference.
\end{abstract}

\section{INTRODUCTION}

In general, the internal control structure of the organization (which is also called the internal control system) including policies and procedures, which provide relative certainty of achieving organizational objectives, arise. Evaluation of the structure is performed by internal auditors, who eventually result in a report called reporting, internal controls and management to users within the organization or outside the organization will be partly used. (Bin Mohamed, 2001). Internal control is very important for auditors. More than any other factor determining the quality of internal control procedures is the auditors. The management report on internal controls has been discussed. The issue of internal control, the audit process by the special characteristics and unique auditing standards is important. because the auditor must have sufficient understanding of the accounting and internal control system for designing and developing the overall audit plan and audit the effectiveness achieved. The current business environment pressure on executives to have a narrow view of the low level has been entered. the focus on low levels for higher productivity, leading to the creation of a support organization. Reporting on internal control managers, managers of the importance of knowledge, strength and ability will encourage internal control structure. As a result of such reports, the executive director may be high levels of accountability regarding internal control systems afford. (Takas, 1993). to outline the main questions that this study has been done to respond to it. It is important to examine the role of administrators and auditors examine internal controls. Internal controls and reporting associated with it is very important for auditors. Quality of internal controls more than any other factor, determines how the auditors' inquiries. The management report on internal controls has been discussed. The issue of internal control, the audit process through the unique special features and auditing standards is very important. because the auditor must have sufficient understanding of the accounting and internal control system for designing and developing the overall audit plan and audit the effectiveness achieved. Comments and opinions of management regarding the internal control system are also very important. As a basis 
for preparing the financial statements and internal control system provides extended response system. Due to the events so far in relation to the non-disclosure of internal control weaknesses in audit reports of companies such as Enron and WorldCom companies in the United States and Iran, which named them unable occurred. Many material and spiritual damage caused to society will need to review the reporting and monitoring tools are not necessary? With regard to the role of managers as agents on the one hand a large number of shareholders who exercise their stewardship responsibility to use the tools for effective use of available resources in order to increase shareholder wealth working. On the one hand auditors as key stakeholders in the reporting arm of the main weaknesses in the internal controls and financial reporting are fundamental. In line with its role as creditors of the financial statements prepared by the Board of Directors, the most relevant groups of respondents to the question of why mandatory reporting, internal controls should be in Iran? These two groups can be named. A long time that the internal controls of a concern for managers and on the other hand, owners and other interested parties on economic entities. because most of the people think that the controls, instruments to achieve the goals of economic unit. The control and management accountability by the managers and employees of the economic entity and requires the participation of all employees are designing and implementing economic unit. The problem is how to ensure reasonable and not absolute by the management of internal controls to provide other interested parties in the economic entity? Is this confidence, not only with financial reporting and the independent auditors' report, it will be possible? The main issue of this study is to compare the administrators and auditors in relation to the issue of whether the internal control reporting is good and improve financial reporting. To achieve this goal it is necessary to answer the following questions: voluntary reporting, internal control is useful? Mandatory reporting, internal control is useful? Voluntary reporting, internal controls can be useful for management decision making? Mandatory reporting, internal controls can be useful for management decision making?

\section{LITERATURE REVIEW}

The research has been reported in the country to assess the feasibility of the demand for internal controls as part of the economic units that are faced by a large part of society, the shareholders have been studied. And to explain various aspects of this issue that demand for internal control reports on the use of information in the companies listed in Tehran Stock Exchange is. respondent groups including stakeholders, public companies listed in Tehran Stock Exchange consists of 4 groups of certified public accountants, internal auditors, experts and students have invested. In this regard, the following results were obtained: Internal control report from the perspective of all user groups to increase the quality of (valuable) data released by the company, especially since the reliability of the information. Internal control reporting improved financial reporting will be mandatory. (Although more people than any other mandatory professional auditors endorse that report.) For all groups of respondents, internal control audit report is to increase its reliability. All groups of respondents, usefulness internal control report with consideration of the increasing interest on the cost of providing it, confirm. (Hermanson, 2000), the demand for internal control reporting through the use of different groups studied in the United States. Overall, the results showed that the respondents agree that internal controls, are bulky. In addition, they generally agree that voluntary reporting, internal controls, management encourages improve internal controls. Audit committees enhance the monitoring process and provide additional information to others. If the report in question be brought into force, respondents felt that the information value is lower. Mandatory reporting, internal controls, information value can be arbitrary in the sense that perhaps the respondents reporting the symbols used in this McMullen et al. (1996) considered. Among M. (2001), this study was conducted in Malaysia. The following is achieved. The theories developed in this study are as follows. Reporting on internal control is useful. Internal control over financial reporting is effective decision-making users. Reporting on internal control of financial reporting improves. The results of the study are as follows: All respondent groups agreed that the 
issue of an organization's internal controls section. Internal control structure appropriate to reduce the risk of fraud and error and weak internal controls will reduce the utility's financial statements. Internal control reporting encourages managers to improve the internal control system. Internal control reports provide useful information for internal and external users provide. Companies should be encouraged to provide such a report should be mandatory for this purpose. The mandatory reporting, internal controls, information value are lower for users. Ogneva and Subramanyam, 2005) primary evidence in connection with the correlation of internal control weaknesses and capital expenditure respectively. The cost of capital of companies that report weaknesses in internal controls, the cost of capital by companies that do not report these cases exposed and investigated. Concluded that a marginal increase in the cost of capital between the companies disclosed weaknesses and companies that do not do there is no disclosure in this regard. Studies evidence in this regard, that the weakness of the internal control system increases uncertainty in the market, respectively. (Doylea ,2007) in their study a test to determine the effects of weaknesses in internal control over financial reporting in connection with the 779 companies listed on the New York Stock Exchange, which has important weaknesses in a report on internal controls for users offer, from August 2002 to 2005 did. The results showed that younger companies whose financial structure is weaker and are being reorganized, with internal control weaknesses are more important. In contrast, companies with better financial structure and older minor weaknesses in internal control weaknesses reported revealed, or not at all companies. They also showed that companies that only have internal controls weaknesses are in a special account, the bigger, older and stronger financial structure compared with companies that have internal control weaknesses in the whole company. Jiang et al. (2009), to investigate and examine this issue, that the relationship between the quality of internal control and audit assessments and assessment of the continuing activities of the company according to the requirements of the Sarbanes-Oxley there in 2002? the research on the companies that during 2004 and 2005, with power and poor financial structure and internal controls had tried to report, pay. The results show that the companies with weak internal control structure and significant weaknesses, they need auditor's opinions and assessments of the company's activities have continued. The analysis shows the significant positive relationship between disclosure and significant weaknesses is a tendency auditors to report on the continuity of the companies that expose their weaknesses are important throughout the entire company.

\section{DATA AND METHODOLOGY}

The main objective of this study was to assess the intellectual capital Tehran Stock Exchange company and test the impact of these variables on the profitability of these companies. The practical aim of this study is quasi-experimental design. To access the desired information for the implementation of the research, all related to Stock Exchange website has been used. To test the partial regression coefficients between the hypothetical dairy research, Spss software is used. When the study is based on financial data forms sometimes provide the main source of financial information for the years 2007 to 2010 in the study were considered. In addition, the notes accompanying the financial forms sometimes provide value-added intellectual capital is used to calculate the index. This study uses data of listed companies in Tehran Stock Exchange as the sample. Hey provide companies with the information from this study have been excluded. Ban perched sector investment and financing and financial profile due to the different and leverage as well as the inherent differences that other companies have been excluded from this study. Samples of 100 companies were considered for 4 years, finally, 458 companies - years were tested. 


\section{RESEARCH HYPOTHESES}

In this study as well as the questions raised in the three groups of hypotheses have been expressed.

a) The hypotheses of the first group to study and understand the importance of internal controls from the perspective of managers and internal auditors.

a- 1) voluntary reporting on internal control management is useful.

a- 2) Mandatory reporting is effective management of internal controls.

a- 3) voluntary reporting of management on internal control, financial reporting in Iran improves.

a- 4) compulsory reporting of management on internal control, financial reporting in Iran improves.

b) The second group of theories: a study from the perspective of understanding the importance of internal auditors.

b- 1) voluntary reporting on internal control management is useful.

b- 2) Mandatory reporting is effective management of internal controls.

b- 3) voluntary reporting of management on internal control, financial reporting improves.

b- 4) compulsory reporting of management on internal control, financial reporting improves.

c) The third hypothesis: Comparison of administrators and auditors.

c- 1) between administrators and auditors regarding the effectiveness of voluntary reporting, internal control management is different.

c- 2) between administrators and auditors regarding the effectiveness of internal controls management, there is mandatory reporting.

c- 3) between administrators and auditors in the voluntary reporting, internal controls, financial reporting improves, there is a difference.

c- 4) between administrators and auditors in respect of the mandatory reporting, internal controls, financial reporting improves, there is a difference.

\section{CONCEPTUAL MODEL}

This study has used survey methods. In other words, the aim of this study is applied. On the other hand, as this study emphasizes differences of opinion, the comparative method is used. I.e. on the basis of data collected from public audit institutions Iranian official in Tehran (the Securities and Exchange organizations are trusted). The companies listed in Tehran Stock Exchange organization, verify hypotheses, test and compare the viewpoints of the two sides, the results will be generalized to the whole population (inductive-deductive). The research, public audit of all institutions Iranian official in Tehran (trustee of the Stock Exchange) and all companies listed on the Stock Exchange in Tehran. In this study, auditors and managers used to respond to questions. Independent internal audit function is almost similar, internal auditors evaluate primary mission control in order to ensure the effective implementation of internal controls. the task of evaluating independent auditors as well as internal controls to ensure that financial statements are to provide the optimal image. the fact that greater coordination and cooperation among (controls) inside and outside efforts, resources and costs to be saved, it has been discussed. the persons responsible for decision-making at the top levels of the organization, managers are. This study is trying to investigate the issue as to whether the internal control reporting high levels of management decision-making management is effective or not? In this study, a questionnaire has been drawn up on the basis of random sampling. a randomly selected sample of community members when they observed an equal chance of being selected. Total population consisted of 488 audit firms, including 122 qualified auditor accountability (senior auditor, supervisors and managers) and number of the managers of 181 companies responding to 724 qualified director (chief accountant, financial manager, internal auditors and financial and administrative assistant ) is. Use the following method to sample size and sample size of 215 managers, 251 are auditors. Information on the sample was selected as described in Table 1. 
Table 1: Data collected and distributed.

\begin{tabular}{|c|c|c|c|c|}
\hline Groups & distributed & collected & lack of response, & $\begin{array}{c}\text { percentage of } \\
\text { answers }\end{array}$ \\
\hline Group auditors & 215 & 213 & 2 & $99 \%$ \\
\hline Group executives & 251 & 250 & 1 & $99 \%$ \\
\hline
\end{tabular}

Table 2: Descriptive statistics, sample management education.

\begin{tabular}{|c|c|c|c|}
\hline Description & frequency & percent & percent stacked \\
\hline Diploma & 32 & 12.8 & 12.8 \\
\hline BA & 127 & 50.8 & 63.6 \\
\hline Master of Science & 65 & 26 & 89.6 \\
\hline PhD & 26 & 10.4 & 100 \\
\hline Sum & 250 & 100 & - \\
\hline
\end{tabular}

Table 3: Classification of managers on the job.

\begin{tabular}{|c|c|c|c|}
\hline Description & frequency & percent & percent stacked \\
\hline Chief Accountant & 49 & 19.6 & 19.6 \\
\hline Financial Manager & 94 & 37.6 & 57.2 \\
\hline $\begin{array}{l}\text { Administrative and } \\
\text { Financial Assistant }\end{array}$ & 46 & 18.4 & 75.6 \\
\hline Internal auditor & 61 & 24.4 & 100 \\
\hline Total & 250 & 100 & - \\
\hline
\end{tabular}

Table 4: Classification of managers based on work experience.

\begin{tabular}{|c|c|c|c|}
\hline Description & frequency & percent & percent stacked \\
\hline Less than 3 years & 15 & 6 & 6 \\
\hline Between 3 and 5 years & 38 & 15.2 & 21.2 \\
\hline $\begin{array}{c}\text { Between } 6 \text { and } 10 \\
\text { years }\end{array}$ & 99 & 39.6 & 60.8 \\
\hline More than 10 years. & 98 & 39.2 & 100 \\
\hline Total & 250 & 100 & - \\
\hline
\end{tabular}

\section{RESULTS AND DISCUSSION}

In the present study to test the hypothesis, the required data collected, processed using Excel and SPSS software is then analyzed as follows:

1. Description: first observations by using descriptive statistics including frequency tables and contingency, statistical graphs and indicators of central tendency and dispersion are described.

2. Inference: Observations study using inferential statistics, using a sample and two-sample t-test and nonparametric test was analyzed Wilcoxon.

6.1. The first group of hypotheses:

Viewpoints managers and internal auditors in connection with the internal control reporting. Descriptive statistics for managers and internal auditors in Tables 2, 3 and 4 are provided. as you can see the average education level of managers on the second floor (BA) and $50.8 \%$ of the sample volume to be allocated. Moreover, financial managers on the job with the highest prevalence with $37.6 \%$ and in terms of working experience, most managers with $39.2 \%$ of the sample have work experience of more than ten years old. Continue to evaluate the results of hypotheses Group a (administrators and internal auditors in connection with the internal control reporting) will pay. The results of the first hypothesis (a-1) the view of managers and internal auditor's first hypothesis is as follows: Voluntary reporting of management on internal control is useful. Relevant statistical output is provided in Appendix 1. As in Appendix 1, the mean of the responses given to the second hypothesis of the managers, and greater than 3, and 3.872 significant level of less than $5 \%$. It should be stated that $95 \%$ of voluntary reporting on internal controls, from the viewpoint managers and internal auditors is useful. So I accepted that the claim is verified. The results of the second 
hypothesis (a- 2) the view of managers and internal auditors, the second hypothesis is as follows: Mandatory reporting of internal control is useful for statistical outputs, in Appendix 2 Provided. As can be observed, the mean of the responses given to the second hypothesis of the managers, and greater than 3 is 3.464 and a significance level of less than $5 \%$. Therefore, the $95 \%$ confidence level, it can be argued that mandatory reporting on internal controls management, from the perspective of managers and internal auditors is useful. Therefore, the claim is considered accepted and approved. The results of the third hypothesis (a -3) from the perspective of managers and internal auditors third hypothesis is as follows: Voluntary reporting of management on internal control, financial reporting in Iran improves. statistical outputs, is presented in Appendix 3. According to information contained in the statistical tables above, the mean responses for the third hypothesis of the managers, and greater than 3 are 3.128 and a significance level of less than 5\%. Therefore, one can say with $95 \%$ confidence that the view of managers and internal auditors, management voluntary reporting on internal control, financial reporting improves. so accepted that the claim is verified. The results of the fourth hypothesis (a- 4) the view of managers and internal auditors fourth hypothesis is as follows: Mandatory reporting of management on internal control, financial reporting in Iran improves. Relevant statistical output is presented in Appendix 4. According to information contained in the statistical tables above, the average responses of the hypothesis third of the managers, and greater than 3 is 3.024 and the significant level of greater than $5 \%$. Therefore, 95 percent of claims could not be confirmed.

\subsection{The second group of hypotheses}

Viewpoints auditors in connection with the internal control reporting. Descriptive statistics of the independent auditors is presented in Tables 5,6 and 7. As you can see, the education of auditors, on the second floor (BA) is the highest frequency of 43.7. Most of the respondents also were the heads of audit firms that make up the $42.7 \%$ of the sample. The experience of auditors, on the fourth floor (over ten years) is that the sample size is $34 \%$ of the total. The results of the first hypothesis (B-1) from the viewpoint of the independent auditors of the hypotheses were as follows: Voluntary reporting of management on internal control is useful. statistical outputs, is presented in Appendix 5.According to these data, the mean responses for the third hypothesis of the managers, and greater than 3 is 3.434 and a significance level of less than 5\% is rejected. Therefore, $95 \%$ are assumed and claims are true. Therefore, it should be stated that the voluntary reporting of management on internal controls, independent auditors of view is useful. the results of the second hypothesis (b-2) from the perspective of independent auditors. The second hypothesis is as follows: Compulsory management of internal control is useful. statistical outputs, is provided in Appendix 6. According to these data, the mean responses for the third hypothesis of the managers, 3.9124 and is greater than 3 and a significance level of less than $5 \%$ is rejected. Therefore, $95 \%$ are assumed and claims are true. Therefore, it is concluded that mandatory reporting, management of internal controls, independent auditors of view is useful. the results of the third hypothesis (b-3) of the views of independent auditors. The third hypothesis is as follows: Voluntary reporting of management on internal control, financial reporting in Iran improves. statistical outputs, is provided in Appendix 7. According to these data, the mean responses for the third hypothesis of the managers, and greater than 3 are 3.838 and a significance level of less than 5\%. The claim has been approved and 95 rejected. Therefore, we can say that from the perspective of independent auditors voluntary reporting on internal controls management, internal and external decision makers to influence and improve. The results of the fourth hypothesis (b-4) from the viewpoint of the independent auditors. The fourth hypothesis is as follows: Mandatory reporting of management on internal control, financial reporting in Iran improves. statistical outputs, is presented in Appendix 8. According to these data, the mean responses for the third hypothesis of the managers, 3.0704 and is greater than 3 and greater than $5 \%$ is significant. Therefore, the $95 \%$ confidence level, cannot be deemed rejected and the claim is not confirmed. 
Table 5: Descriptive statistics education, independent auditors selected sample.

\begin{tabular}{|c|c|c|c|}
\hline Description & frequency & percent & $\begin{array}{c}\text { percent } \\
\text { stacked }\end{array}$ \\
\hline Diploma & 108 & 50.7 & 50.7 \\
\hline BA & 93 & 43.7 & 94.4 \\
\hline Master of Science & 12 & 56 & 100 \\
\hline PhD & 213 & 100 & - \\
\hline
\end{tabular}

Table 6: Classification of the auditors on the basis of job title.

\begin{tabular}{|c|c|c|c|}
\hline Description & frequency & percent & $\begin{array}{c}\text { percent } \\
\text { stacked }\end{array}$ \\
\hline Senior Auditor & 77 & 36.2 & 36.2 \\
\hline Supervisor & 91 & 42.7 & 78.9 \\
\hline Manager & 45 & 21.1 & 100 \\
\hline Total & 213 & 100 & - \\
\hline
\end{tabular}

Table 7: Classification of Auditors on the basis of their experience.

\begin{tabular}{|c|c|c|c|}
\hline Description & frequency & percent & percent stacked \\
\hline Less than 3 years & 20 & 9.4 & 9.4 \\
\hline $\begin{array}{c}\text { Between 3 and 5 } \\
\text { years }\end{array}$ & 51 & 23.9 & 33.3 \\
\hline $\begin{array}{c}\text { Between 6 and 10 } \\
\text { years }\end{array}$ & 69 & 32.4 & 65.7 \\
\hline More than 10 years. & 73 & 34.3 & 100 \\
\hline Total & 213 & 100 & - \\
\hline
\end{tabular}

6.3. The third group of hypotheses: Comparison of administrators and auditors.

In this section, based on information collected from each group sample, to compare the views of the directors and auditors for each of the hypotheses studied. Note that due to differences in sample size COMMUNITY (251) and the auditors (215), the third group test the hypothesis that we are looking for a comparative study of the two sides. Each view must be examined and tested in pairs. Therefore, given that the number of responses received between 213 and less than managers, auditors. The auditor placed in front of each director and the software used is normally fewer samples (213) were based. The results of the first hypothesis (c-1) compared to the first hypothesis administrators and auditors were as follows: Between administrators and auditors regarding the effectiveness of voluntary reporting, internal control management are different. Statistical outputs to compare the attitudes of managers and independent auditors on the first hypothesis (c-1), is presented in Appendix 9. As shown in the tables contained in Appendix 9, the mean response was more directors and auditors of the numerical value of the test statistic is in the critical area. In other words, even though both groups on the issue of voluntary reporting, internal control is useful especially in management, agreed, but by the auditors in this field, significantly higher than the managers. Considering the disparity of the average responses of managers and auditors, and that the significance level of 5\%. Between administrators and auditors can be said about the management of voluntary reporting on internal control is good, there is a significant difference, rejected the claim is true. It should be noted, however, assume hypotheses Group managers and auditors strongly agreed separately managers regarding the hypothesis of auditors. However, taking into account the fact that the pair has been studied as a comparative analysis of the parties' views, Software used by some of the responses by group managers up to 213 people decreased in comparative perspective the result is the opposite. The second hypothesis test (c 2) to compare the administrators and auditors. The second hypothesis is as follows: Between administrators and auditors about the usefulness of 
mandatory reporting, internal control management is different. Statistical outputs to compare the attitudes of managers and independent auditors on the second hypothesis (c-2), is presented in Appendix 10. As shown in the tables contained in Annex 10, the mean response was more auditors and managers to value the test statistic is in the critical area. In other words, even though both groups on the issue of mandatory reporting, internal control is useful especially in management, agreed. but by managers in the field, significantly higher than the managers. Considering the disparity of the average responses of managers and auditors, and that the significance level of 5\%, between administrators and auditors can be said about the management of compulsory reporting of internal control is good, there is a significant difference. The hypothesis is rejected and the claim has been approved. It should be noted, however, the correlation between managers and auditors separately by the auditors on the severity of the theory of management. However, taking into account the fact that the pair has been studied as a comparative analysis of the parties' views, the software used, some of the responses by group managers up to 213 people reduce the comparative view of the picture test. The results of the third hypothesis (c- 3) compare the attitudes of managers and independent auditors. The third hypothesis is as follows: Between administrators and auditors in the voluntary reporting, internal controls, financial reporting improves, there is a difference. Statistical outputs between administrators and auditors in the third hypothesis (c- 3), Appendix 11 is provided. As shown in the tables contained in Annex 11, the mean response was more directors and auditors of the numerical value of the test statistic is in the critical area. In other words, even though both groups on the issue of voluntary reporting, management of internal control, financial reporting improves, agreed. but by the auditors in this field, significantly higher than the managers. Considering the disparity of responses mean those managers and auditors, and a significance level of less than $5 \%$. Between administrators and auditors can be said about the voluntary reporting on internal control of financial reporting to improve management, there are differences. The hypothesis is rejected and the claim has been approved. the results of the fourth hypothesis (c- 4) between administrators and auditors. The fourth hypothesis is as follows: Between administrators and auditors in respect of the mandatory reporting, internal controls, financial reporting Improves, there is a difference. statistical outputs between administrators and auditors in the fourth hypothesis (c- 4) is presented in Appendix 12. As shown in the tables contained in Appendix 12, although the average responses of the two groups are very close. the mean responses to auditors, managers, more than the numerical value of the test statistic and its critical region. In other words, even though both groups on the issue of mandatory reporting of management on internal control, financial reporting improves, agreed. However, the auditors agreed on this issue are significantly higher than the managers. considering the disparity of directors and auditors and average response times less than the significance level of 0.045 and less than 0.05 . Between administrators and auditors can be said about the management of compulsory reporting on internal controls, financial reporting improves, there is a difference, then the assumption is rejected and the claim is verified.

\section{CONCLUSION}

The results of tests and statistical analyzes indicate that the managers and auditors on this subject agree that voluntary reporting, internal control is useful. According to the company's internal controls, can be a monitoring process to be considered for that conflict of interest between management, shareholders, creditors, and other stakeholders to reduce. Statistical analysis of the effectiveness of internal control reporting has been mandatory. The results of this analysis indicate that the administrators and auditors (with intensity than the management agreement) mandatory reporting of internal controls is recommended. The beneficial effects of the internal control report and the information it has proven value. effect of voluntary reporting on internal controls over financial reporting improvement. It was found that administrators and auditors, management voluntary reporting on internal control, financial reporting improves. Internal control reporting interesting decision makers involved in the corporate governance issues. The basic premise of the general aspects of the matter is that the internal control reporting, financial reporting improves 
quality and reduces the problems of governance. If this account is correct, reporting, internal control can be regarded as a regulatory mechanism those conflicts of interest between management, shareholders, creditors and other stakeholders to reduce. Although the average responses of managers and auditors on the effectiveness of mandatory reporting, internal control over financial reporting improvement is close to the average population. However, considering the significance level of the test, the results obtained from administrators and auditors, management mandatory reporting on internal control, financial reporting does not improve. While proponents argue that additional information relating to the reporting of internal control reports to improve the usefulness of the system. however, no guarantee that these benefits will be fulfilled in this regard does not exist. Both managers and auditors to perform statistical analysis views on the need for reporting internal controls were studied. It was concluded that between administrators and auditors' report on internal control managers, there is a significant difference. The hypotheses were tested hypotheses of 9, 8 hypothesis was confirmed, and this shows that the views of both managers and auditors of internal control reporting improved financial reporting will be mandatory. And with regard to the issue listed companies should be obliged to submit such a report. according to the results of this study and the fact that the main part of an organization's internal control and its importance from the viewpoint of auditors and administrators is proven. the need for more research studies and the strengthening of internal control Systems Company. It also meets the demands of auditors (when trying to plan and perform the audit tests rely on the system). And management's expectations in this regard (to play better job of his stewardship and protection of assets and enhance the effectiveness and efficiency of operations) will be met. In this connection a report indicating all the flaws, faults, strengths and weaknesses are internal control system. And lights better way to improve the internal control system as a basis for decision-making to managers and investors who need information quality (not quantity, such as financial statements), which is.

\section{Attachments}

Appendix 2- The results of the second hypothesis $(\mathrm{A}-2)$ from the perspective of managers and internal auditors.

One-Sample Statistics

\begin{tabular}{|l|r|r|r|c|}
\hline & $\mathrm{N}$ & \multicolumn{1}{|c|}{ Mean } & Std. Deviation & $\begin{array}{c}\text { Std. Error } \\
\text { Mean }\end{array}$ \\
\hline MEAN3 & 250 & 3.4640 & .66317 & .04194 \\
\hline
\end{tabular}

One-Sample Test

\begin{tabular}{|c|c|c|c|c|c|c|}
\hline & \multicolumn{6}{|c|}{ Test Value $=3$} \\
\hline & \multirow[b]{2}{*}{$t$} & \multirow[b]{2}{*}{$d f$} & \multirow[b]{2}{*}{ Sig. (2-tailed) } & \multirow{2}{*}{$\begin{array}{c}\text { Mean } \\
\text { Difference }\end{array}$} & \multicolumn{2}{|c|}{$\begin{array}{c}95 \% \text { Confidence } \\
\text { Interval of the Difference }\end{array}$} \\
\hline & & & & & Lower & Upper \\
\hline MEAN3 & 11.063 & 249 & .000 & .4640 & .3814 & .5466 \\
\hline
\end{tabular}


Appendix 3 - The third hypothesis testing (A - 3) from the perspective of managers and internal auditors.

One-Sample Statistics

\begin{tabular}{|l|r|r|r|c|}
\hline & \multicolumn{1}{|c|}{$\mathrm{N}$} & \multicolumn{1}{c|}{ Mean } & Std. Deviation & $\begin{array}{c}\text { Std. Error } \\
\text { Mean }\end{array}$ \\
\hline MEAN6 & 250 & 3.1280 & .83210 & .05263 \\
\hline
\end{tabular}

One-Sample Test

\begin{tabular}{|c|c|c|c|c|c|c|}
\hline & \multicolumn{6}{|c|}{ Test Value $=3$} \\
\hline & \multirow[b]{2}{*}{$t$} & \multirow[b]{2}{*}{ df } & \multirow[b]{2}{*}{ Sig. (2-tailed) } & \multirow{2}{*}{$\begin{array}{c}\text { Mean } \\
\text { Difference }\end{array}$} & \multicolumn{2}{|c|}{$\begin{array}{c}95 \% \text { Confidence } \\
\text { Interval of the Difference }\end{array}$} \\
\hline & & & & & Lower & Upper \\
\hline MEAN6 & 2.432 & 249 & .016 & .1280 & .0244 & .2316 \\
\hline
\end{tabular}

Appendix 4 - The results of the fourth hypothesis (A - 4) the view of managers and internal auditors

One-Sample Statistics

\begin{tabular}{|l|r|r|r|c|}
\hline & $\mathrm{N}$ & \multicolumn{1}{|c|}{ Mean } & Std. Deviation & $\begin{array}{c}\text { Std. Error } \\
\text { Mean }\end{array}$ \\
\hline MEAN7 & 250 & 3.0240 & .72216 & .04567 \\
\hline
\end{tabular}

One-Sample Test

\begin{tabular}{|c|c|c|c|c|c|c|}
\hline & \multicolumn{6}{|c|}{ Test Value $=3$} \\
\hline & \multirow[b]{2}{*}{$t$} & \multirow[b]{2}{*}{$d f$} & \multirow[b]{2}{*}{ Sig. (2-tailed) } & \multirow{2}{*}{$\begin{array}{c}\text { Mean } \\
\text { Difference }\end{array}$} & \multicolumn{2}{|c|}{$\begin{array}{c}95 \% \text { Confidence } \\
\text { Interval of the Difference }\end{array}$} \\
\hline & & & & & Lower & Upper \\
\hline MEANT & .525 & 249 & .600 & .0240 & -.0660 & .1140 \\
\hline
\end{tabular}


Appendix 5 - The results of the first hypothesis (B - 1) in the eyes of independent auditors.

One-Sample Statistics

\begin{tabular}{|c|r|r|r|c|}
\hline & $\mathrm{N}$ & \multicolumn{1}{|c|}{ Mean } & Std. Deviation & $\begin{array}{c}\text { Std. Error } \\
\text { Mean }\end{array}$ \\
\hline MEAN2 & 213 & 3.4343 & .58713 & .04023 \\
\hline
\end{tabular}

One-Sample Test

\begin{tabular}{|c|c|c|c|c|c|c|}
\hline & \multicolumn{6}{|c|}{ Test Value $=3$} \\
\hline & \multirow[b]{2}{*}{$t$} & \multirow[b]{2}{*}{ df } & \multirow[b]{2}{*}{ Sig. (2-tailed) } & \multirow{2}{*}{$\begin{array}{c}\text { Mean } \\
\text { Difference }\end{array}$} & \multicolumn{2}{|c|}{$\begin{array}{c}95 \% \text { Confidence } \\
\text { Interval of the Difference }\end{array}$} \\
\hline & & & & & Lower & Upper \\
\hline MEAN2 & 10.795 & 212 & .000 & .4343 & .3550 & .5136 \\
\hline
\end{tabular}

Appendix 6 - The results of the second hypothesis (B - 2) from the perspective of independent auditors.

One-Sample Statistics
\begin{tabular}{|l|r|r|r|c|}
\hline & $\mathrm{N}$ & Mean & Std. Deviation & $\begin{array}{c}\text { Std. Error } \\
\text { Mean }\end{array}$ \\
\hline MEAN3 & 213 & 3.9124 & .68039 & .04662 \\
\hline
\end{tabular}

One-Sample Test

\begin{tabular}{|c|c|c|c|c|c|c|}
\hline & \multicolumn{6}{|c|}{ Test Value $=3$} \\
\hline & \multirow[b]{2}{*}{$t$} & \multirow[b]{2}{*}{$\mathrm{df}$} & \multirow[b]{2}{*}{ Sig. (2-tailed) } & \multirow{2}{*}{$\begin{array}{c}\text { Mean } \\
\text { Difference }\end{array}$} & \multicolumn{2}{|c|}{$\begin{array}{c}95 \% \text { Confidence } \\
\text { Interval of the Difference }\end{array}$} \\
\hline & & & & & Lower & Upper \\
\hline MEAN3 & 19.570 & 212 & .000 & .9124 & .8205 & 1.0043 \\
\hline
\end{tabular}

Appendix 7 - The results of the third hypothesis (B - 3) of the views of independent auditors.

One-Sample Statistics

\begin{tabular}{|c|r|r|r|c|}
\hline & $\mathrm{N}$ & Mean & Std. Deviation & $\begin{array}{c}\text { Std. Error } \\
\text { Mean }\end{array}$ \\
\hline MEAN6 & 213 & 3.8380 & .77143 & .05286 \\
\hline
\end{tabular}

One-Sample Test

\begin{tabular}{|c|c|c|c|c|c|c|}
\hline & \multicolumn{6}{|c|}{ Test Value $=3$} \\
\hline & \multirow[b]{2}{*}{$t$} & \multirow[b]{2}{*}{ df } & \multirow[b]{2}{*}{ Sig. (2-tailed) } & \multirow{2}{*}{$\begin{array}{c}\text { Mean } \\
\text { Difference }\end{array}$} & \multicolumn{2}{|c|}{$\begin{array}{c}95 \% \text { Confidence } \\
\text { Interval of the Difference }\end{array}$} \\
\hline & & & & & Lower & Upper \\
\hline MEAN6 & 15.854 & 212 & .000 & .8380 & .7338 & .9422 \\
\hline
\end{tabular}


Appendix 8 - Results of the fourth hypothesis (B - 4) from the viewpoint of the independent auditors.

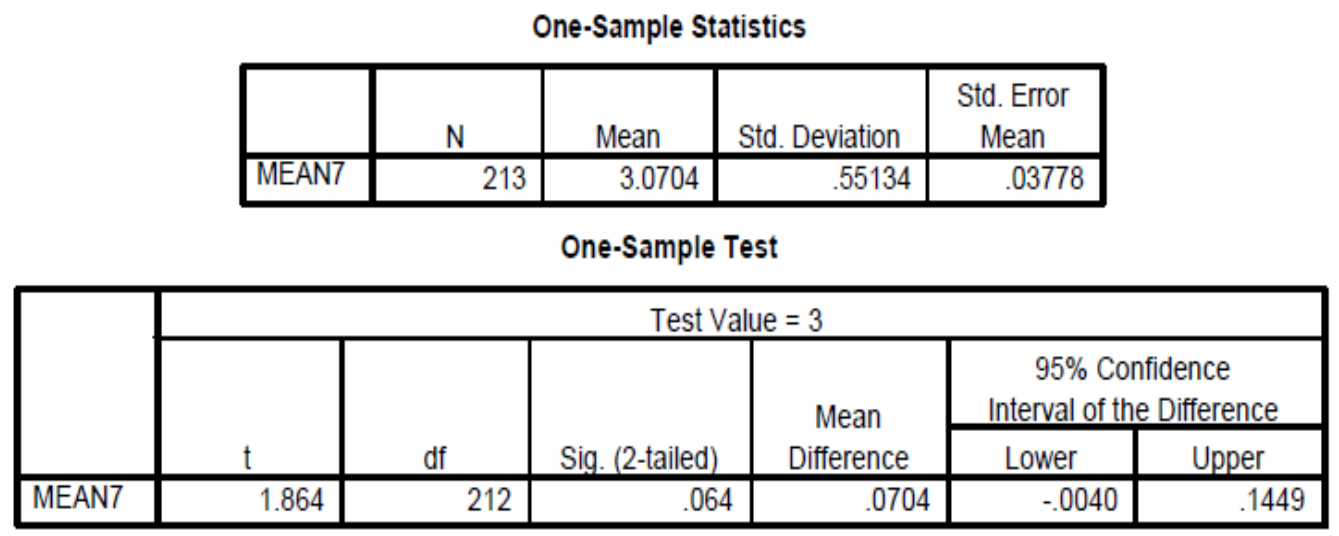

Appendix 9 - The results of the first hypothesis (C-1) comparing the attitudes of managers and independent auditors.

Paired Samples Statistics

\begin{tabular}{|c|c|c|c|c|c|}
\hline & & Mean & $\mathrm{N}$ & Std. Deviation & $\begin{array}{c}\text { Std. Error } \\
\text { Mean }\end{array}$ \\
\hline \multirow[t]{2}{*}{ Pair1 } & $\begin{array}{l}\text { Coercive report \& } \\
\text { useful(manager) }\end{array}$ & 3.4444 & 213 & .64725 & .04435 \\
\hline & $\begin{array}{l}\text { Coercive report \& } \\
\text { useful(audit) }\end{array}$ & 3.9124 & 213 & .68039 & .04662 \\
\hline
\end{tabular}

Paired Samples Test

\begin{tabular}{|c|c|c|c|c|c|c|c|c|}
\hline & \multicolumn{5}{|c|}{ Paired Differences } & \multirow[b]{3}{*}{$t$} & \multirow[b]{3}{*}{$d f$} & \multirow[b]{3}{*}{ bia. (2-tailec } \\
\hline & \multirow[b]{2}{*}{ Mean } & \multirow[b]{2}{*}{ tt. Deviatiol } & \multirow{2}{*}{$\begin{array}{l}\text { Std. Error } \\
\text { Mean }\end{array}$} & \multicolumn{2}{|c|}{$\begin{array}{l}95 \% \text { Confidence } \\
\text { enval of the Differen }\end{array}$} & & & \\
\hline & & & & Lower & Upper & & & \\
\hline \begin{tabular}{l|l} 
Pair 1 Coercive report\& $\&$ useful|(manage \\
Coercive report \& useful(audit)
\end{tabular} & -.4679 & .89175 & .06110 & -.5884 & -3475 & .7 .658 & 212 & 00 \\
\hline
\end{tabular}


Appendix10-The results of the second hypothesis (C-2) compare the attitudes of managers and independent auditors.

Paired Samples Statistics

\begin{tabular}{|l|l|r|r|r|r|}
\hline \multicolumn{2}{|c|}{} & \multicolumn{1}{|c|}{ Mean } & $\mathrm{N}$ & Std. Deviation & $\begin{array}{c}\text { Std. Error } \\
\text { Mean }\end{array}$ \\
\hline Pair 1 & $\begin{array}{l}\text { Voiuntry report \& Decision } \\
\text { making(manager) }\end{array}$ & 3.7746 & 213 & .83605 & .05729 \\
\cline { 2 - 5 } & $\begin{array}{l}\text { Voiuntry report \& Decision } \\
\text { making(audit) }\end{array}$ & 3.1244 & 213 & .80813 & .05537 \\
\hline
\end{tabular}

Paired Samples Test

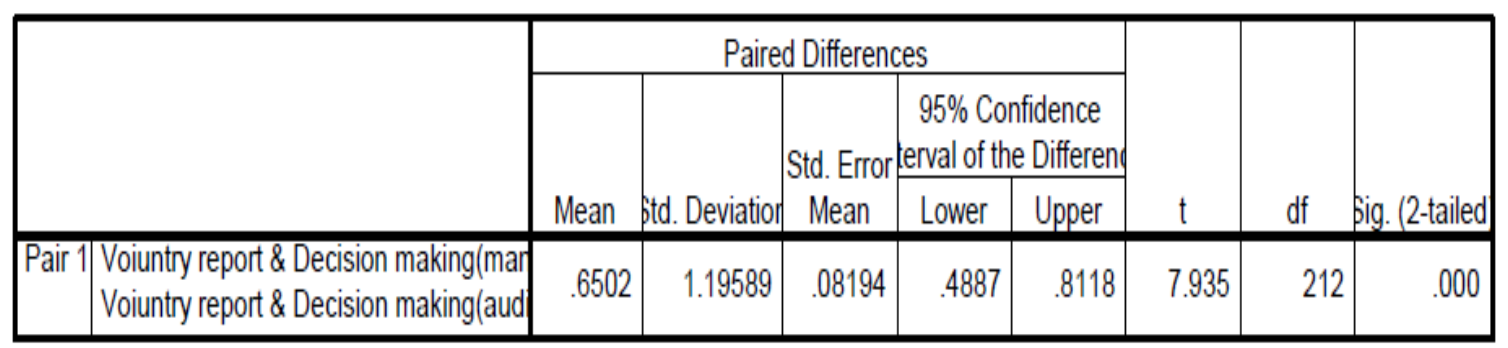

Appendix 11 - The results of the third hypothesis (C-3) compare the attitudes of managers and independent auditors.

Paired Samples Statistics

\begin{tabular}{|l|r|r|r|r|r|}
\hline \multicolumn{2}{|c|}{} & \multicolumn{1}{|c|}{ Mean } & $\mathrm{N}$ & Std. Deviation & $\begin{array}{c}\text { Std. Error } \\
\text { Mean }\end{array}$ \\
\hline Pair 1 & $\begin{array}{l}\text { Voluntary report \& } \\
\text { improvement(manager) }\end{array}$ & 3.0634 & 213 & .78125 & .05353 \\
\cline { 2 - 6 } & $\begin{array}{l}\text { Voluntary report \& } \\
\text { improvement(audit) }\end{array}$ & 3.8380 & 213 & .77143 & .05286 \\
\hline
\end{tabular}

Paired Samples Test

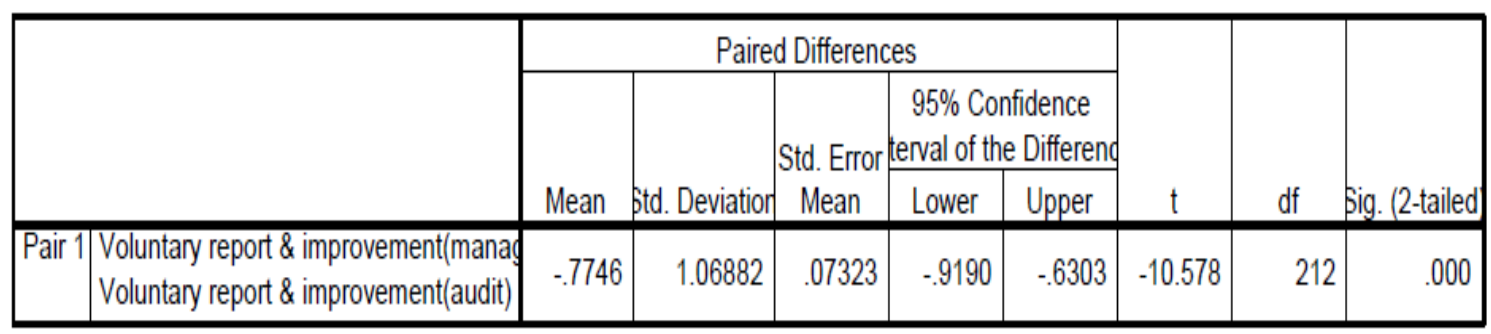


Appendix12- The results of the fourth hypothesis (C-4) compare the attitudes of managers and independent auditors.

Paired Samples Statistics

\begin{tabular}{|l|l|r|r|r|r|}
\hline \multicolumn{2}{|l|}{} & \multicolumn{1}{|c|}{ Mean } & $\mathrm{N}$ & Std. Deviation & $\begin{array}{c}\text { Std. Error } \\
\text { Mean }\end{array}$ \\
\hline Pair 1 & $\begin{array}{l}\text { Coercive report \& } \\
\text { improvement(manager) }\end{array}$ & 2.9742 & 213 & .66803 & .04577 \\
\cline { 2 - 6 } & $\begin{array}{l}\text { Coercive report \& } \\
\text { improvement(audit) }\end{array}$ & 3.0704 & 213 & .55134 & .03778 \\
\hline
\end{tabular}

Paired Samples Test

\begin{tabular}{|c|c|c|c|c|c|c|c|c|c|}
\hline & \multicolumn{5}{|c|}{ Paired Differences } & \multirow[b]{3}{*}{$t$} & \multirow[b]{3}{*}{$d f$} & \multirow[b]{3}{*}{ Sig. (2-tailed } \\
\hline & & \multirow[b]{2}{*}{ Mean } & \multirow[b]{2}{*}{ Std. Deviation } & \multirow{2}{*}{$\begin{array}{l}\text { Std. Emor } \\
\text { Mean }\end{array}$} & \multicolumn{2}{|c|}{\begin{tabular}{|c|}
$95 \%$ Confidence \\
nterval of the Difference
\end{tabular}} & & & \\
\hline & & & & & Lower & Upper & & & \\
\hline & $\begin{array}{l}\text { Coercive report \& improvement(manage } \\
\text { Coercive report \& improvement(audit) }\end{array}$ & -0962 & .81053 & .05554 & -2057 & .0132 & -5.733 & 212 & .045 \\
\hline
\end{tabular}

\section{References}

[1] Committee of Sponsoring Organization of the Tread way Commission (COSO), (1992), Internal Control - Integrated Framework. New York, NY: AICPA.

[2] Commission on Auditors' Responsibilities (The Cohen Commission), (1978), the Commission on Auditors' Responsibilities Report, Conclusion and Recommendation. New York, NY: AICPA.

[3] General Accounting Office (GAO), (1992), Letter from Donald H. Chapin, Assistant Comptroller General, GAO, to Robert L. May, Chairman, Committee of Sponsoring Organizations of the Tread way Commission. (October 30), Journal of Accountancy.

[4] Hermanson, H. M., (2000), "An Analysis of the Demand for Reporting on Internal Control" Accounting Horizons. Vol. 14, No. 3, pp. 325- 341.

[5] MOHAMED, Z.,( 2001), an Empirical Study on the Directors and Auditors' Perception Relating to the Demand for Reporting on Internal Control, UNIVERSITI TEKNOLOGI MARA.

[6] National Commission on Fraudulent Final Reporting (NCFFR) (The Trade way commission), (1987), Report of the National Commission on Fraudulent Financial Reporting, New York, NY: NCFFR.

[7] S. Hammersley, j., A. Myers, 1., Shakespeare, c.,( 2007), Market reactions to the disclosure of internal control weaknesses and to the characteristics of those weaknesses under section 302 of the Sarbanes Oxley Act of 2002, Rev Acc Stud (2008) 13: 141-165.

[8] Mcmullen, D.A., K, Ranjunandan and, D.V. Rana., (1996). Internal control report and financial reporting problems. Accounting Horizons, 10 (December): 67-75.

[9] U.S. House of Representatives,( 1985), Hearingsbefore the Subcommittee on Oversight Investigations of the House Committee on Energy and Commerce, 20 February, pp 99- 117.

[10] Doyle, J., Ge, W., McVay, S., (2007), D eterminants of weaknesses in internal control. 